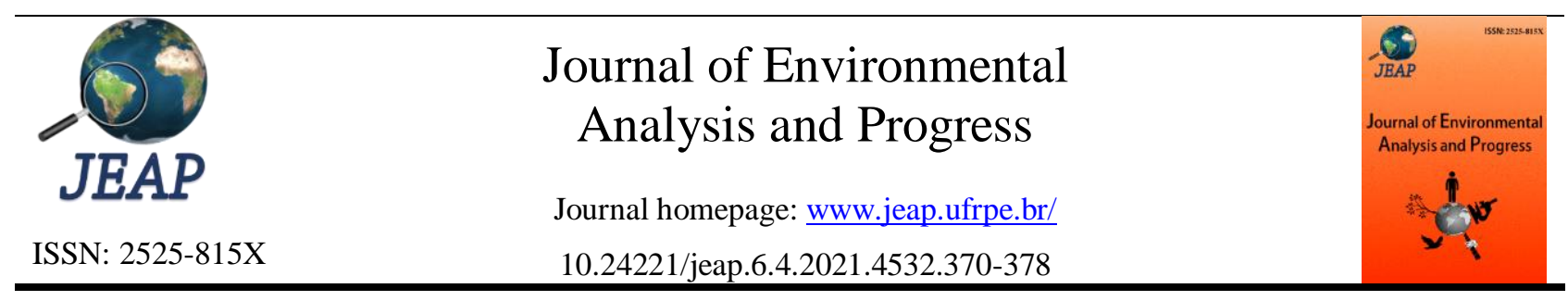

\title{
Interaction soil compaction and soil moisture in physiological responses of freshly planted coffee
}

Samuel Dias Moreira ${ }^{a}$, André Cabral França ${ }^{a}$, Ricardo Siqueira da Silva ${ }^{\text {a }}$, Rita de Cassia Ribeiro Carvalho ${ }^{\mathrm{b}}$, Fabrício Resende de Aguiar

${ }^{\text {a }}$ Universidade Federal dos Vales do Jequitinhonha e Mucuri-UFVJM, Departamento de Ciências Agrárias, Campus JK. Rodovia MGT 367, Km 683, $\mathrm{n}^{\circ}$ 5.000, Alto da Jacuba, Diamantina-MG, Brasil. CEP: 39100-000. E-mail: agronomia_samuel@yahoo.com.br, cabralfranca@gmail.com, ricardo.ufvjm@gmail, fabricio.r.a1996@gmail.com.

b Universidade do Estado de Minas Gerais-UEMG, Faculdade de Agronomia. Avenida Juca Stockler, n 1130 , Bairro Belo Horizonte, Passos-MG, Brasil. CEP: 37900-106. E-mail: rita.carvalho@ fespmg.edu.br.

\section{A R T I C L E I N F O \\ Received 16 Aug 2021}

Accepted 20 Nov 2021r

Published 24 Nov 2021

\begin{abstract}
A B S T R A C T
In the field, coffee is subject to the stress of soil compaction and lack of water, which may cause changes in the physiological responses of the plant. The objective of this study was to evaluate the physiological responses of the coffee tree under different soil moisture content and compaction degrees in the soil subsurface. The experimental design was in blocks, arranged in a factorial scheme, with four replications. The first factor corresponds to the two wetlands, 50 and $100 \%$ of the soil field capacity, and the second corresponds to 60,70, 80, and $90 \%$ of soil subsurface compaction. The experimental plot consisted of a Coffea arabica L. plant grown on a polyvinyl chloride column. The physiological responses were evaluated at 180 days of planting. The different compaction degrees and soil moisture content influenced the photosynthetic rate, carbon consumption, $\mathrm{CO} 2$ concentration in the substomatal chamber, internal carbon / atmospheric carbon ratio, water efficiency, and absolute coffee growth rate. The transpiration rate and the root weight ratio were influenced only by the humidity, instead of the stomatal conductance and the foliar temperature, by degrees of compaction. The ratio of root system per soil layer was influenced by compaction degrees and soil depth. The limitation of root growth and lack of water are the main causes of decreased physiological responses. Subsurface compaction and water deficit together potentiate negatively on the physiological responses of freshly seeded coffee plants.
\end{abstract}

Keywords: Coffea arabica, water deficit, water availability, abiotic factors, plant physiology.

\section{Introduction}

Brazil is the largest producer and exporter of coffee globally, having registered a record production of 62.5 million bags in the crop year from March 2018 to April 2019 (International Coffee Organization-ICO, 2019). Coffee plantations in the country occupy a total area of 2.16 million hectares, of which $15 \%$ are in formation, and $85 \%$ are in production (National Supply Company-CONAB, 2019).

Technologies are important for coffee growing, such as irrigation, which enabled the expansion of coffee growing to areas with water deficits. Irrigation ensures greater productivity (Sakai et al., 2015; Fernandes et al., 2016) and coffee quality (Sakai et al., 2013). The machines participate partially or fully in the coffee production operations, and some of the benefits are cost-benefit and operational efficiency. Mechanized harvesting, for example, is more viable than manual harvesting as it provides a better response to economic indicators (Lanna \& Reis, 2012), reduced operating costs, and higher yields (Santinato et al., 2015).

The intensified use of machinery in coffee production exerts great pressure on the soil and, consequently, increases the density of particles and, in an extreme situation, causes soil compaction. Compaction reduces porosity, water permeability, water, and nutrient availability and increases soil resistance to penetration (Oliveira et al., 2010). The mechanized cultivation system in coffee plantations causes greater soil resistance to penetration, especially in the passage line, 
compared to the manual cultivation system (Palma et al., 2013).

Soil moisture is directly related to soil resistance to plant root penetration (Silveira et al., 2010) and soil compaction. Intensive machine traffic causes excessive soil compaction in coffee plantations, and inadequate moisture enhances particle aggregation (Kamimura et al., 2012). The intensity of machine traffic, associated with high water levels in the soil, reduces the productivity and height of soybean plants due to soil compaction (Oliveira et al., 2012). It is advisable to avoid machine traffic when soil moisture is high, resulting in increased soil density and compaction (Ahmadi \& Ghaur, 2015).

Despite the benefits for coffee production, machine traffic and irrigation can if handled inappropriately, cause compaction and excess water in the soil, respectively compromising the development of the crop. This study was carried out to evaluate the physiological responses of the coffee tree under different moisture content and degrees of compaction in the subsurface of the soil.

\section{Material and Methods}

The study was conducted from January to December 2018 in a greenhouse at the Federal University of the Jequitinhonha and Mucuri, located in Diamantina, Minas Gerais State, Brazil $\left(18^{\circ} 12^{\prime} 12.27^{\prime \prime S}, 43^{\circ} 34^{\prime} 17.95^{\prime \prime} \mathrm{W}\right.$ and altitude of $1.403 \mathrm{~m})$.

The experimental design was in randomized blocks, arranged in a $2 \times 4$ factorial scheme, with four replications. The first factor corresponds to two soil moistures, $50 \%$ and $100 \%$ of the soil's field capacity (FC), and the second corresponds to $60 \%, 70 \%, 80 \%$, and $90 \%$ of soil compaction degrees. The experimental portion consisted of a coffee plant per polyvinyl chloride column (PVC), totaling 32 units.

The Rubi MG 1192 cultivar seeds were immersed in sodium hypochlorite $(1 \%)$ for 4 minutes and then rinsed with distilled water. Seeds were sown in tubes and irrigated daily. The period of seedling formation was from January to May 2018, reaching five pairs of leaves and, on average, $11 \mathrm{~cm}$ of aerial part height, $0.25 \mathrm{~cm}$ of stem diameter, $6.5 \mathrm{~g}$ of total green weight, and $1.6 \mathrm{~g}$ total dry weight. The coffee seedlings were produced in tubes of $100 \mathrm{ml}$, containing commercial substrate and cattle manure in the proportion 5:1, respectively. This initial evaluation of the plants was obtained through ten additionally produced seedlings, which followed the same growth pattern as the seedlings used in the experiment.

PVC tubes of $150 \mathrm{~mm}$ were cut horizontally, forming rings $10 \mathrm{~cm}$ high. Four PVC rings were overlaid and glued with adhesive tape, creating a column $40 \mathrm{~cm}$ high. The inner wall of the column was coated with a $2 \mathrm{~mm}$ thick layer of paraffin to prevent lateral leakage of water in the region of the soil/column interface (Figure 1).

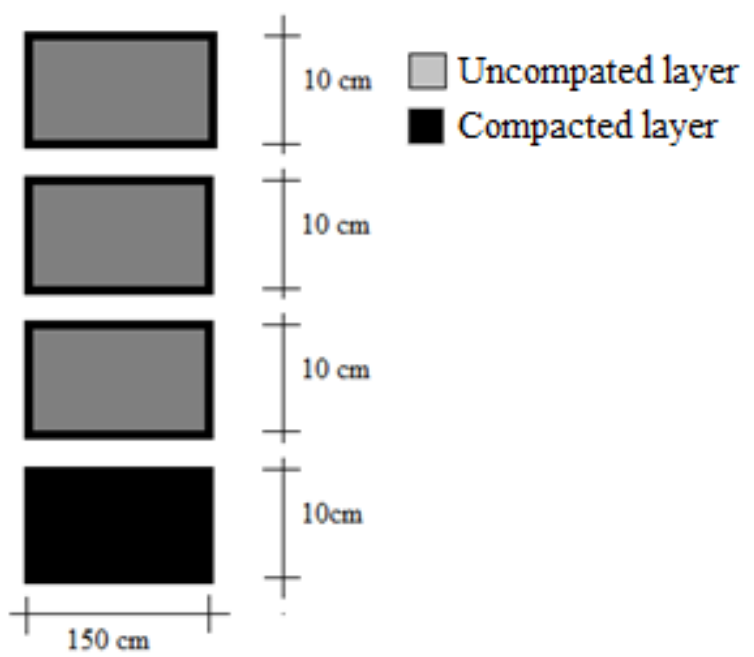

Figure 1. Representative illustration of polyvinyl chloride column. Font: Moreira et al. (2021).

The substrate used was a eutrophic RedYellow Latosol (Ferralsols) (Santos et al., 2018). The soil was submitted to the Proctor test, according to the NBR 7182 standard (Brazilian Association of Technical Standards-ABNT, 1986). The maximum density of the soil is obtained according to the optimum compaction moisture. The maximum density (DSmax) was $1,54 \mathrm{~g} \mathrm{~cm}^{-3}$, with an optimum moisture content of $21 \%$. Soil compaction was defined with degrees of compaction (DC) 60\%, 70\%, 80\% and 90\% and, based on these determinations, the relative density (RD) was calculated, RD = Field density / DSmax; $\mathrm{DC}=\mathrm{RD} * 100$.

In June, the seedlings were planted in PVC columns and kept at $80 \%$ humidity of the FC. The FC was determined by the Richards chamber (Brazilian Agricultural Research CorporationEMBRAPA, 1997) at a voltage of $6 \mathrm{kPa}$, resulting in $0,34 \mathrm{~kg} \mathrm{~kg}^{-1}$. The coffee tree was mulched with a $1 \%$ ammonium sulfate solution, $80 \mathrm{ml}$ of the solution for each plant, on days 15 and 25 after planting.

According to the recommendation for the coffee tree, and simple superphosphate fertilizer was applied for planting coffee seedlings (Guimarães et al., 1999). The soil was submitted to chemical and granulometric analysis (Table 1) (Brazilian Agricultural Research CorporationEMBRAPA, 1997), being sieved in a $4 \mathrm{~mm}$ mesh. Subsequently, the degree of compaction for each treatment was applied only to the last PVC ring, 30 to $40 \mathrm{~cm}$ deep, representing subsurface 
compaction. The $60 \%$ compaction degree was maintained for the other column depths, 0 to $30 \mathrm{~cm}$ (Figure 1).

Table 1. Characterization of the eutrophic RedYellow Latosol (Ferralsols) used for coffee cultivation before fertilization. Font: Moreira et al. (2021).

\begin{tabular}{|c|c|c|c|c|}
\hline \multirow{2}{*}{$\mathbf{p H}$} & OM & $\mathbf{P}$ & $\mathbf{K}$ & Ca \\
\hline & Dag kg-1 & \multicolumn{2}{|c|}{$\mathrm{Mg} \mathrm{dm}^{-3}$} & Cmolc dm $\mathrm{dm}^{-3}$ \\
\hline 5,97 & 3,36 & 32,73 & 262,36 & 5,03 \\
\hline Mg & Al & $\mathbf{H}+\mathbf{A l}$ & SB & $\mathbf{t}$ \\
\hline \multicolumn{5}{|c|}{ - } \\
\hline 2,28 & 0,02 & 2,81 & 8,08 & 8,10 \\
\hline $\mathbf{m}$ & V & Sand & Clay & Silt \\
\hline \multicolumn{5}{|c|}{$\%$} \\
\hline 0,24 & 74 & 25 & 51 & 24 \\
\hline
\end{tabular}

$\mathrm{pH}$ water $=$ soil-water ratio $1: 2,5 ; \mathrm{OM}=$ organic matter - colorimetric method; $\mathrm{P}, \mathrm{K}, \mathrm{Cu}, \mathrm{Fe}, \mathrm{Mn}$ and $\mathrm{Zn}$ - Mehlich-1 extractor; $\mathrm{Ca}, \mathrm{Mg}$ and $\mathrm{Al}-\mathrm{KCl}$ extractor $1 \mathrm{~mol} \mathrm{~L}^{-1} ; \mathrm{H}+\mathrm{Al}-0.5 \mathrm{~mol} \mathrm{~L}^{-1}$ calcium acetate; $\mathrm{SB}=$ sum of bases; $\mathrm{t}=$ effective cation exchange capacity; $\mathrm{m}=$ aluminum saturation; $\mathrm{V}=$ base saturation.

After 30 days of planting, treatments $50 \%$ and $100 \%$ of FC were applied in the experimental plots. The soil moisture control was performed using an electronic meter (Hidrofarm - model HFM2030), irrigating until each treatment reached the corresponding soil moisture.

At 180 days after planting, the experiment was evaluated. The physiological characteristics, including photosynthetic rate, consumed carbon, $\mathrm{CO} 2$ concentration in the substomatal chamber, internal carbon/atmospheric carbon ratio, stomatal conductance, transpiration rate, leaf temperature, and water use efficiency (photosynthesis/transpiration), were measured using an infrared gas analyzer (IRGA), brand ADC, model LCA 4 (Analytical Development Co. Ltd., Hoddesdon, UK) under saturation irradiation of $1.200 \mu \mathrm{mol}$ photons $\mathrm{m}^{-2} \mathrm{~s}^{-1}$. Physiological characteristics were measured in three fully expanded and healthy leaves positioned in the middle third of the coffee tree. The evaluations were carried out between 8 and 10 am with clear skies and natural lighting.

The dry weight of the aerial part of the coffee tree was determined in an oven with forced air circulation at $65^{\circ} \mathrm{C}$ until it reached constant weight. The absolute growth rate (AGR) of the coffee tree was calculated using the equation AGR $=($ initial dry weight - final dry weight $) / 180$ days; initial dry weight, final dry weight, and 180 days refer to the average weight of seedlings, weight after 180 days of planting and time interval between the two samples, respectively.

The roots were fractioned according to the rings, every $10 \mathrm{~cm}$ in-depth, and sieved to separate them from the soil in the columns. The roots were washed with running water and placed in greenhouses, obtaining the dry weight for each corresponding depth. Subsequently, the total dry weight of the roots was the sum of the four layers. The root weight ratio (RWR) and the coffee root system to soil layer ratio (CSRS) were calculated by the ratio between the total dry weight of the roots and the total dry weight of the coffee plant and by the ratio of the dry weight of the roots of a given layer and total dry weight of roots, respectively.

Data were subjected to analysis of variance using the $F$ test $(p \leq 0.05)$, in which the significant interaction was broken down using regression analysis between relative densities. The Tukey test was performed at $5 \%$ in the root data.

\section{Results}

Soil moisture and the degree of soil compaction altered the physiological responses of the coffee tree. The degree of soil compaction (DC) was given in percentage and represented the relative density $\left(\mathrm{g} \mathrm{cm}^{-3}\right)$ based on the maximum density. The $50 \%$ and $100 \%$ moisture content of the soil's field capacity (FC) represented the water deficit (WD) and the optimal water condition for coffee growth, respectively. The interaction between WD and the increase in DC negatively affected the physiological responses of the coffee tree.

The photosynthetic rate, consumed carbon, $\mathrm{CO} 2$ concentration in the substomatal chamber, internal carbon/atmospheric carbon ratio, water use efficiency, and the absolute growth rate of the coffee tree were influenced by different degrees of compaction and soil moisture. The transpiration rate and the root weight ratio were influenced only by the moisture content, instead of the stomatal conductance and leaf temperature, which were influenced by the degrees of compaction. The root system to soil layer ratio was influenced by the degree of compaction and soil depth.

The photosynthetic rate of the coffee tree decreased with the increase of the DC in the subsurface, with accentuated variation in the FC. However, little variation in the WD from $70 \%$ DC. Soil with $60 \%$ DC increased the photosynthetic rate by $115 \%$ and $150 \%$ in $\mathrm{WD}$ and $\mathrm{FC}$, respectively, compared to $90 \%$ DC. WD reduced by half the photosynthetic rate concerning FC. Coffee in the best condition, FC, and 60\% DC increased the photosynthetic rate by $250 \%$ 
compared to the worst condition, WD and $90 \%$ DC

(Figure 2A).

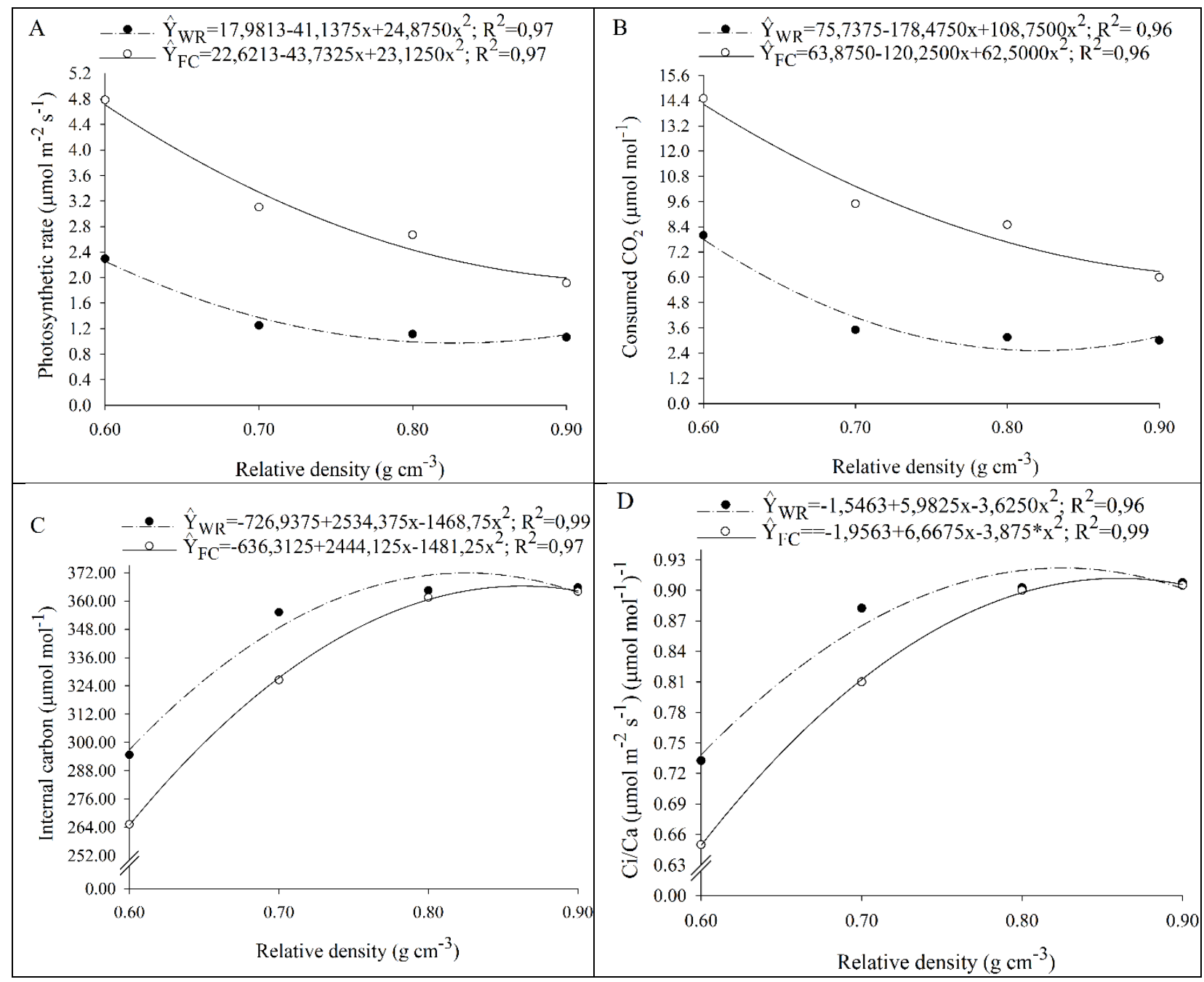

Figure 2. A. Photosynthetic rate; B. Consumed carbon; C. CO2 concentration in the substomatal chamber; D. Internal carbon/atmospheric carbon ratio (iC/aC) of Coffea arabica L. (Rubi MG-1192) plants at different moistures and different relative soil densities (degrees of compaction), at a depth of 30 to $40 \mathrm{~cm}$ of soil field capacity (FC) and water restriction (WR) $=50 \%$ of soil field capacity. Font: Moreira et al. (2021).

The carbon consumed by the coffee tree had similar behavior to the photosynthetic rate. The consumed carbon decreased with the increase of the DC in the subsurface, with accentuated variation in the $\mathrm{FC}$; however, little variation in the WD at $70 \%$ DC. Soil with $60 \%$ DC increased WD carbon consumed by $167 \%$ and $\mathrm{FC}$ carbon consumed by $142 \%$, compared to $90 \%$ DC. FC increased by $131 \%$ the carbon consumed about WD. The coffee tree in the best condition, FC and DC at $60 \%$, increased the carbon consumed by 283\% compared to the worst condition, WD and DC at $90 \%$ (Figure 2B).
The coffee tree's $\mathrm{CO} 2$ concentration in the substomatal chamber (Figure 2C) and the internal carbon/atmospheric carbon ratio (Figure 2D) showed maximum values at $83 \%$ and $86 \%$ DC in WD and FC, respectively. The WD provided higher $\mathrm{CO} 2$ concentration in the substomatal chamber and a higher internal carbon/atmospheric carbon ratio about FC; however, the values approached 80\% DC.

The stomatal conductance of the coffee tree did not differ between soil moistures. The relationship between stomatal constancy and DC was proportionally inverse; the extremes of DC reached a difference of $80 \%$ (Figure 3A). 


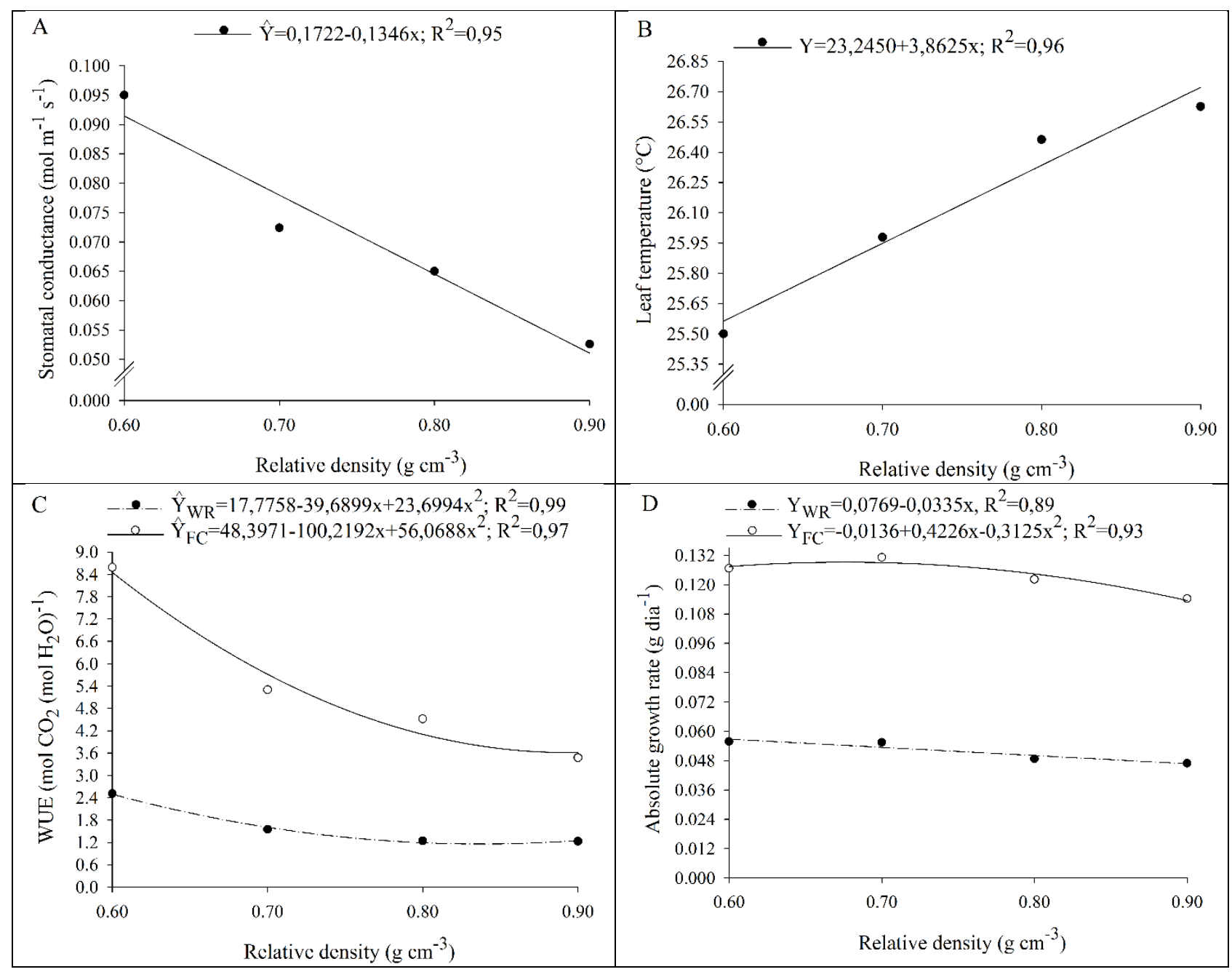

Figure 3. A. Stomatal conductance of water vapors; B. Leaf temperature; C. Water use efficiency (WUE); D. Absolute growth rate of Coffea arabica L. plants at different moistures and different relative soil densities (degrees of compaction), at a depth of 30 to $40 \mathrm{~cm}$ of soil field capacity (FC) and water restriction (WR) = $50 \%$ of soil field capacity. Font: Moreira et al. (2021).

The transpiration rate of the coffee tree was higher in WD condition, approximately $54 \%$ about FC (Table 2). The coffee leaf temperature increased as the DC increased; however, the temperature variation was less than $2^{\circ} \mathrm{C}$. Soil moisture did not influence leaf temperature (Figure 3B).

Table 2. Transpiratory rate and root weight ratio of Coffea arabica L. (Rubi MG-1192) coffee at 50\% and $100 \%$ field capacity. Font: Moreira et al. (2021).

\begin{tabular}{|c|c|c|}
\hline $\begin{array}{c}\text { Soil field capacity } \\
(\%)\end{array}$ & $\begin{array}{c}\text { Transpiratory rate } \\
\left(\mathrm{mol} \mathrm{H}_{2} \mathrm{O} \mathrm{m}^{2} \mathrm{~s}^{-1}\right)\end{array}$ & $\begin{array}{c}\text { Root weight ratio } \\
(\mathrm{g} / \mathrm{g})\end{array}$ \\
\hline 50 & $0,8769 \mathrm{a}$ & $0,3198 \mathrm{~b}$ \\
\hline 100 & $0,5719 \mathrm{~b}$ & $0,3474 \mathrm{a}$ \\
\hline Overall average & 0,7244 & 0,3336 \\
\hline CV $(\%)$ & 11,62 & 7,24 \\
\hline
\end{tabular}

Averages followed by the same letter in the column do not differ from each other, by the Tukey test, at 5\% probability.

The efficient use of water on the coffee tree decreased with the increase of the DC in the subsurface with an accentuated variation of FC, however, with little variation of WD. Soil with $60 \%$ DC increased the efficient use of water by $104 \%$ and $147 \%$ in WD and FC, respectively, compared to $90 \%$ DC. The efficient use of water was increased $232 \%$ by the FC, on average, compared to the WD. The coffee plant in the best condition, FC, and $60 \%$ DC increased water use efficiency by $595 \%$, compared to the worst condition, WD and 90\% DC (Figure 3C). 
The absolute growth rate of the coffee tree showed low variation between DC and high variation between soil moistures. 90\% DC decreased the absolute growth rate of WD and FC by $20 \%$ and $11 \%$, respectively, compared to $60 \%$ DC. FC increased the absolute growth rate by an average of $140 \%$ compared to WD (Figure 3D). Regarding WD, the coffee root weight ratio was slightly higher in FC, about 9\% (Table 2).
The coffee root system per soil layer ratio (CRSR) presented an interaction between the degree of compaction and Table 2 depth in the soil profile for the FC condition but not for the WD condition. In $60 \%$ DC, layers 2, 3, and 4 had the same CRSR, and the first layer was the highest. At other values for DC, as the compaction of the last soil layer increased, the CRSR in this layer decreased, and the others increased, mainly in the third layer (Figure 4).

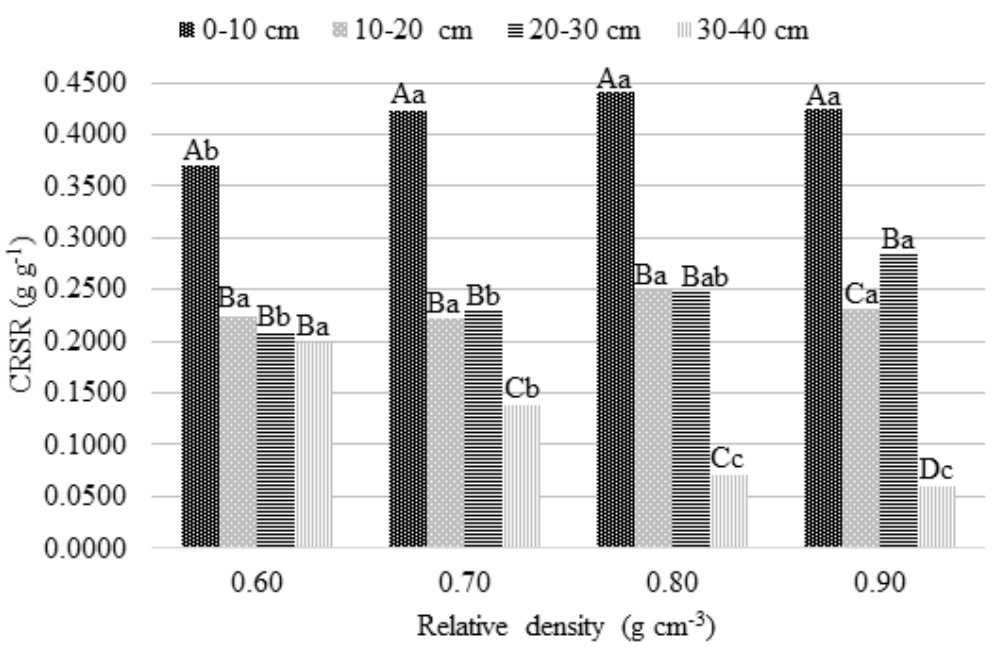

Figure 4. Coffee root system to soil layer ratio (CRSR) of Coffea arabica L. (Rubi MG-1192) at different relative soil densities (degrees of compaction), at depths of 30 to $40 \mathrm{~cm}$, under different soil depths. Averages followed by the same uppercase letter within each respective density and lowercase letter within each depth do not differ from each other, by Tukey's test, at 5\% probability. Font: Moreira et al. (2021).

\section{Discussion}

The photosynthetic rate was always higher in coffee grown on FC compared to WD, regardless of DC. The highest irrigation depth $\left(1.2 \mathrm{~mm} \mathrm{day}^{-1}\right)$ provided a higher photosynthetic rate for the coffee tree about the smaller depths (Garcia et al., 2019). Coffee in WD decreased the photosynthetic rate (Tesfaye et al., 2014) associated with lower use of photochemical energy and increases in energy dissipation in the form of bloom and heat. It indicates inefficiency in the synthesis of ATP and NADPH due to the decrease in light energy and the transport of electrons (Peloso et al., 2017).

The photosynthetic rate is related to $\mathrm{CO} 2$ consumption and $\mathrm{CO} 2$ concentration in the substomatal chamber. A plant with a high photosynthetic rate requires a greater consumption of $\mathrm{CO} 2$. On the other hand, the internal $\mathrm{CO} 2$ concentration of the leaf mesophyll is inversely proportional to the $\mathrm{CO} 2$ consumption (Galon et al., 2010). In the case of abiotic stress, WD decreases the photosynthetic rate by reducing $\mathrm{CO} 2$ consumption, increasing the $\mathrm{CO} 2$ concentration in the substomatal chamber.

The relationship between internal carbon and atmospheric carbon decreases with the consumption of $\mathrm{CO} 2$; as the consumption of $\mathrm{CO} 2$ increases, the difference in its gradient between the external and internal environment of the leaf. Due to this gradient, $\mathrm{CO} 2$ will enter the leaf faster through the stomatal opening (Silveira et al., 2012). Carbon fixation reactions are inefficient when the internal carbon and atmospheric carbon ratio approaches 1 (Guerra, Costa \& Tavares, 2017). With this information, the coffee tree under water deficit was inefficient in carbon fixation about FC.

The stomatal conductance had no difference in soil moisture; however, it would normally decrease under lower water availability (Peloso et al., 2017). The stomatal closure leads to a reduction in stomatal conductance (Scalon et al., 2011). The plant assimilates $\mathrm{CO} 2$ from the atmosphere through the stomata to use in photosynthesis. However, water is lost when exposing this opening. The entry of $\mathrm{CO} 2$ and the exit of water occur through the same orifice, thus creating a conflict between the plant's need to conserve water and absorb $\mathrm{CO} 2$. Stomatal opening and closing are among the adaptations of plants to control water loss through leaves (Taiz et al., 2017). 
Soil moisture was constant in the cultivation of the coffee tree, and, as a result, the coffee tree underwent adaptations to these conditions. Even in WD, the plant maintained its stomatal opening and leaf temperature, trying to conserve $\mathrm{CO} 2$ entry and avoid a lower photosynthetic rate for its growth. Consequently, the transpiration rate increased, and the water use efficiency decreased. In FC conditions, the high photosynthetic rate compensates for transpiration, increasing the efficiency of water use by the coffee tree. FC increased water use efficiency compared to WD (Liu et al., 2016).

The absolute growth rate of the coffee tree was reduced in cultivation under lower water availability due to the negative effects of physiological responses, providing a lower plant growth about FC. The relative growth rate of coffee is higher in FC than in WD (Cavatte et al., 2012). The coffee tree growth decreased as the soil water availability reduced (Moreira et al., 2018), and both the vegetative and reproductive stages were affected by WD (Aparecido \& Rolim, 2018). Normally, plant growth under water stress is reduced due to its decrease in photosynthetic rate (Liu et al., 2016).

The root weight ratio is the ratio between the root system and the plant's total weight and, therefore, the higher this ratio, the greater the investment in root production. The root weight ratio under WD was reduced to about $\mathrm{FC}$, and the irrigated treatments had higher root concentrations than non-irrigated treatments (Sakai et al., 2015). The plant, strategically, tries to maintain root growth to fetch water from the soil in a WD situation and, therefore, the difference in the root weight ratio between FC and WD for the coffee tree was small.

The coffee root system ratio (CRSR) is the proportion of roots for each soil layer about the total and, therefore, it was possible to see where the highest concentration of roots is. The compaction of the soil subsurface had little or no interference in CRSR in the WD condition, as the coffee tree under DH concentrated the roots in the 0 to $30 \mathrm{~cm}$ layer, barely reaching the compacted layer. In FC condition, roots had no water impediment to their growth and reached the compacted layer. Irrigation treatments provide greater soil profile rooting than treatments without irrigation (Sakai et al., 2015).

Soil compaction increased root diameter and reduced root elongation, and the elongation rate was influenced by soil resistance to penetration (Popova et al., 2016). The compaction of the soil subsurface influenced the CRSR, mainly the last two layers (20 to 30 and 30 to $40 \mathrm{~cm}$ ); in the last layer of soil, the higher the DC, the lower was
CRSR. The root weight ratio did not change with the DC. However, the roots had different concentrations in the soil profile according to the DC. When considering compensates for the lower development in the compacted layers, the roots increase the less compacted layers (Beuter \& Centurion, 2004). When the CRSR decreased in the last layer, the CRSR increased in the penultimate soil layer.

In general, the physiological responses were negatively affected by the increase in DC, which caused a reduction in the photosynthetic rate of the coffee tree associated with a reduction in the root in the compacted layer. The decrease in $\mathrm{CO} 2$ consumption and stomatal conductance and the increase in internal $\mathrm{CO} 2$ concentration and internal carbon/atmospheric carbon ratio support the lower photosynthetic rate in the high DC condition.

Soil compaction negatively influences plant physiology and growth, due to the reduction in specific root length, in the proportion of fine roots and root xylem vessels (Alameda \& Vilar, 2012). Severe compaction levels decreased the photosynthetic rate, the transpiration rate, and the stomatal conductance compared to lower levels. When associated with 14 days of drought in the soil, the physiological responses decreased even more (Grzesiak et al., 2016).

Roots limited by soil compaction cause changes in the physiological responses of plants, which can be explained by lower root exploration capacity, lower absorption of water and nutrients (Alameda \& Vilar, 2012). High DC affects the spatial distribution of the root system, the efficiency of water uses, and the absolute growth rate of the coffee tree.

Climatic variationsClimatic variations mainly cause fluctuations in coffee yields in the world. Coffee tree growth is influenced by environmental factors, such as reduced rainfall, and high temperatures are responsible for drought (Cheserek \& Gichimu, 2012). The interaction between mechanical impediment to root growth and soil drought is potentially negative for plant development and yield (Susuki et al., 2018).

Therefore, given the relevance of using technologies in the current intensive coffee production, it is pertinent to carry out field studies to, in addition to the correlation of the behaviors observed in this study, elucidate such effects on the production and final quality of coffee.

\section{Conclusion}

The physiological responses of the coffee tree were negatively affected by subsurface compaction and soil water deficit. The limitation of root growth and lack of water were the main causes 
of the decrease in physiological responses. The subsurface compaction and water deficit together potentiated the negative effect on the physiological responses of freshly planted coffee seedlings.

\section{Acknowledgements}

This study was carried out with the support of the Coordination for the Improvement of Higher Education Personnel - Brazil (CAPES) - Financing Code 001.

\section{References}

Ahmadi, I.; Ghaur, H. 2015. Effects of soil moisture content and tractor wheeling intensity on traffic-induced soil compaction. Journal of Central European Agriculture, 16, 489-502.

http://dx.doi.org/10.5513/JCEA01/16.4.1657

Alameda, D.; Villar, R. 2012. Linking root traits to plant physiology and growth in Fraxinus angustifolia Vahl. seedlings under soil compaction conditions. Environmental and Experimental Botany, 79, 49-57. https://doi.org/10.1016/j.envexpbot.2012.01. 004

Aparecido, L. E. O.; Rolim, G. S. 2018. Forecasting of the annual yield of Arabic coffee using water deficiency. Brazilian Agricultural Research, 53, 1299-1310. https://doi.org/10.1590/S0100204X2018001200002

Beuter, A. N.; Centurion, J. F. 2004. Soil compaction on root development and soybean yield. Brazilian Agricultural Research, 39, 581-588.

Brazilian Agricultural Research Corporation EMBRAPA. 1997. Manual of soil analysis methods. Brasília, DF: National Center for Soil Research, Second Edition. 212p.

Brazilian National Standards Organization-ABNT. NBR 7182: Soil: compaction test. 1986. Rio de Janeiro. 10p.

Cavatte, P. C.; Rodriguez-Lopez N. F.; Martins, S. C. V.; Mattos, M. S.; Sanglard, L. M. V. P; DaMatta, F. M. 2012. Functional analysis of the relative growth rate, chemical composition, construction and maintenance costs, and the payback time of Coffea arabica L. leaves in response to light and water availability. Journal of Experimental Botany, 63, https://doi.org/10.1093/jxb/ers027 3071-3082.

Cheserek, J. J.; Gichimu, B. M. 2012. Drought and heat tolerance in coffee: a review. International Research Journal of Agricultural Science and Soil Science, 2, 498501.
Fernandes, A. L. T.; Tavares, T. de O.; Santinato, F.; Ferreira, R. T.; Santinato, R. 2016. Technical and economic viability of drip irrigation of coffee in Araxá, MG. Coffee Science, 11, 347-358.

Galon, L.; Ferreira, F. A.; Silva, A. A.; Concenço, G.; Ferreira, E.A.; Barbosa, M. H. P.; Silva, A. F.; Aspiazú, I; França, A. C.; Tironi, S. P. 2010. Influence of herbicides on the photosynthetic activity of sugarcane genotypes. Weed, 28, 591-597.

Garcia, F. H. S.; Matute, A. F. M.; Silva, L. C. da; Santos, H. R. B.; Botelho, D. dos S.; Rodrigues, M.; Barbosa, J. P. R. A. D. 2019. Physiological analysis in coffee seedlings showing brown eye spot under different irrigation levels. Summa Phytopathologica, 45, 83-88. https://doi.org/10.1590/0100$5405 / 185711$

Grzesiak, M. T.; Janowiak, F.; Szczyrek, P.; Katarzyna, K.; Ostrowska, A.; Rut, G.; Hura, T.; Rzepka A.; Grzesiak, S. 2016. Impact of soil compaction stress combined with drought or waterlogging on physiological and biochemical markers in two maize hybrids. Acta Physiologiae Plantarum, 38, 1-15. https://doi.org/10.1007/s11738-016-2128-4

Guerra, A. M. N. M.; Costa, A. C. M.; Tavares, P. R. F. 2017. Photosynthetic activity and yield of lettuce grown under shading. Technical Agricultural Magazine, 38, 125-132

Guimarães, P. T. G.; Garcia, A. W. R.; Venegas, V. H. A.; Prezotti, L. C.; Viana, A. E.; Malavolta, E.; Corrêa, J. B.; Lopes, A. S.; Nogueira, F. D.; Monteiro, A. V. C.; Oliveira, J. A. de. 1999. Cafeeiro. In: Ribeiro, A. C.; Gontijo, P. T.; Alvarez, V. H. [eds.]. Minas Gerais State Soil Fertility Commission. Recommendations for the use of correctives and fertilizers in Minas Gerais: 5th approach, pp. 289-302.

International Coffee Organization-ICO: Trade Statistics Tables. Available at: https://www.conab.gov.br. Access at: May 6, 2019.

Kamimura, K. M.; Dias Junior, M. de S.; Guimarães, P. T. G.; Santos, G. R. dos; Oliveira, M. S. de. 2012. Load bearing capacity of a Red-Yellow Latosol in a coffee plantation. Brazilian Journal of Soil Science, 36 , 1457-1465.

https://doi.org/10.1590/S010006832012000500009

Lanna, G. B. M.; Reis, R. P. 2012. Influence of harvest mechanization in economic and financial viability of coffee farming in 
southern Minas Gerais. Coffee Science, 7, 110-121.

Liu, X.; Li, F.; Zhang, Y.; Yang, Q. L. 2016. Effects of deficit irrigation on yield and nutritional quality of Arabica coffee (Coffea arabica) under different $\mathrm{N}$ rates in dry and hot region of southwest China. Agricultural Water Management, 172, 1-8. http://dx.doi.org/10.1016/j.agwat.2016.04.00 7

Moreira, S. D.; França, A. C.; Rocha, W. W.; Tibães, E. S. R.; Neiva Júnior. 2018. Inoculation with mycorrhizal fungi on the growth and tolerance to water deficit of coffee plants. Brazilian Journal of Agricultural and Environmental Engineering, 22, 747-752. https://doi.org/10.1590/1807-

1929/agriambi.v22n11p747-752

National Supply Company - CONAB: Coffee Newsletter January 2019. Available at: https://www.conab.gov.br. Access at: May 6, 2019

Oliveira, V. S.; Rolim, M. M.; Vasconcelos, R. F. B.; Costa, Y. D. J.; Pedrosa, E. M. R. 2010. Compaction of a Ultisol submitted to different managements. Brazilian Journal of Agricultural and Environmental Engineering, 14, 914-920. https://doi.org/10.1590/S141543662010000900002

Oliveira, P. R. de; Centurion, M. A. P da C.; Franco, H. B. J.; Centurion, J. F. 2012. Physical quality of an oxisol under soybean at different compaction and irrigation levels. Brazilian Journal of Soil Science, 36, 587597. $\quad$ http://dx.doi.org/10.1590/S010006832012000200028

Palma, M. A. Z.; Volpato, C. E. S.; Silva, F. C.; Souza, P. de; Silva, J. A. 2013. Soil penetration resistance in coffee plantations cultivated with mechanized and manual systems. Coffee Science, 8, 364-370.

Peloso, A. F.; Tatagiba, S. D.; Reis, E. F.; Pezzopane, J. E. M.; Amaral, J. F. T. 2017. Photosynthetic limitations in leaves of Arabic coffee promoted by the water deficit. Coffee Science, 12, 389-399.

Popova, L.; Dusschoten, D. V.; Nagel, K. A.; Fiorani, F.; Mazzolai, B. 2016. Plant root tortuosity: an indicator of root path formation in soil with different composition and density. Annals of Botany, 118, 685-698. https://doi.org/10.1093/aob/mcw057

Sakai, E.; Barbosa, E. A. A.; Silveira, J. M. de C.; Pires, R. C. de M. 2013. Coffea arabica (cv Catuaí) production and bean size under different population arrangements and soil water availability. Agricultural Engineering, 33, 145-156. https://doi.org/10.1590/S010069162013000100015

Sakai, E.; Barbosa, E. A. A.; Silveira, J. M. de C.; Pires, R. C. de M. 2015. Coffee productivity and root systems in cultivation schemes with different population arrangements and with and without drip irrigation. Agricultural Water Management, 148, 16-23. https://doi.org/10.1016/j.agwat.2014.08.020

Santinato, F.; Ruas, R. A. A.; Silva, R. P. da; Duarte, A. P.; Santinato, R. 2015. Economic analysis of harvesting coffee using repeat operations. Coffee Science, 10, 402-411.

Santos, H. G. dos; Jacomine, P. K. T.; Anjos, L. H. C. dos; Oliveira, V. A. de; Lumbreras, J. F.; Coelho, M. R.; Almeida, J. A. de; Araújo Filho, J. C. de A.; Oliveira, J. B. de; Cunha, T. J. F. 2018. Brazilian System of Soil Classification, Brasília-DF, Fifth Edition. 356p.

Scalon, S. de P. Q.; Mussury, R. M.; Euzébio, V. L. de M.; Kodama, F. M.; Kissmann, C. 2011. Water stress in metabolism and initial growth of mutambo (Guazuma ulmifolia Lam.) seedlings. Forest Science, Santa Maria, 21, 655-662. https://doi.org/10.5902/198050984510

Silveira, D. C.; Melo Filho, J. F. do; Sacramento, J. A. S. do S.; Silveira, E. C. P. 2010. Relationship between the soil water content and root penetration resistance of a Dystrocohesive Yellow Argissol. Brazilian Journal of Soil Science, 34, 659-667. https://doi.org/10.1590/S010006832010000300007

Silveira, H. M.; Silva, D. V.; Carvalho, F. P. de; Castro Neto, M. D. de; Silva, A. A. da. 2012. Photosynthetic characteristics of cassava cultivars treated with fluazifop-p-butyl and fomesafen. Revista Agroambiente 6, 222227.

Taiz, L.; Zeiger, E.; Moller, I. A.; Murphy, A. 2017. Physiology and plant development, Porto Alegre, Sixth Edition. 888p.

Tesfaye, S. G.; Ismail, M. R.; Ramlan, M. F.; Marziah, M.; Kausar, H. 2014. Effect of soil drying on rate of stress development, leaf gas exchange and proline accumulation in Robusta coffee (Coffea canephora Pierre ex Froehner) clones. Experimental Agriculture, 50 , 458-479. https://doi.org/10.1017/S001447971300063 $\mathrm{X}$ 